\title{
Meir M. Bar-Asher. Le rapport de la religion nuṣayrite-'alawite au shi'isme imâmite
}

\section{Mathieu Terrier}

\section{Q OpenEdition}

1 Journals

\section{Édition électronique}

URL : http://journals.openedition.org/abstractairanica/40282

DOI : 10.4000/abstractairanica.40282

ISSN : 1961-960X

Éditeur :

CNRS (UMR 7528 Mondes iraniens et indiens), Éditions de l'IFRI

\section{Édition imprimée}

Date de publication : 1 décembre 2013

ISSN : 0240-8910

\section{Référence électronique}

Mathieu Terrier, "Meir M. Bar-Asher. Le rapport de la religion nușayrite-'alawite au shi'isme imâmite », Abstracta Iranica [En ligne], Volume 32-33 | 2013, document 360, mis en ligne le 01 juillet 2016,

consulté le 26 septembre 2020. URL : http://journals.openedition.org/abstractairanica/40282 ; DOI : https://doi.org/10.4000/abstractairanica.40282

Ce document a été généré automatiquement le 26 septembre 2020.

Tous droits réservés 


\section{Meir M. Bar-Asher. Le rapport de la religion nuṣayrite-'alawite au shi'isme imâmite}

Mathieu Terrier 


\section{RÉFÉRENCE}

Meir M. Bar-Asher. « Le rapport de la religion nuṣayrite-'alawite au shi'isme imâmite ", in : Mohammad-Ali Amir-Moezzi, Meir M. Bar-Asher, Simon Hopkins, éds., Le shī'isme im āmite quarante ans après. Hommage à Etan Kohlberg. Turnhout, Brepols, 2009, p. 73-93.

1 Si la religion nuṣayrite a souvent été présentée comme un syncrétisme, son rapport spécifique avec le chiisme imāmite a été jusqu'à présent peu étudié. L'article entend combler cette lacune en montrant à la fois l'ancrage du nuṣayrisme dans l'imāmisme et son rapport de distanciation avec lui. Son fondateur éponyme, Ibn Nuṣayr al-Namīrī (ou al-Numayrī), aurait été un disciple du dixième (m. 254/868) ou du onzième imam (m. 260/873-4) de la tradition duodécimaine; la secte semble avoir émergé dans un climat de rivalité entre disciples des imams. S'il développe des idées propres aux Chiites «exagérateurs» (gulāt), le nuṣayrisme se considère lui-même comme le "vrai chiisme ». Sa position ambivalente par rapport à l'imāmisme est manifeste dans ses rituels commémorant les évènements de Ġadīr Hुumm et de 'Āšūrā'. Ce dernier reçoit une interprétation "docétiste » et se voit célébré par une fête. Suite à sa période de formation, l'histoire du nuṣayrisme est peu documentée jusqu'au début de l'ère coloniale qui marque à un tournant: la secte semble éradiquer ses aspects les plus « hétérodoxes » pour se présenter comme une branche du chiisme imāmite, ce dont témoigne son changement de nom en 'alawisme. L'article montre que ces efforts pour identifier le nuṣayrisme à l'imāmisme, même dictés par des raisons politiques comme en Syrie, reposent sur des bases doctrinales solides.

\section{AUTEURS}

\section{MATHIEU TERRIER}

Paris 